\title{
Genetic Stability and Disease Resistance Analysis of Hrpzpsta Gene in Transgenic Soybean Lines
}

\author{
Miao Yu ${ }^{1}$, Peiwu Wang ${ }^{1}$, Yang Song ${ }^{1}$,Yong Qi Feng ${ }^{1}$, Jing $\mathrm{Qu}^{1}$,Jie Rong ${ }^{1}$, Mo Zhang ${ }^{1} \&$ Zhuo Zhang ${ }^{1}$ \\ ${ }^{1}$ Center for Plant Biotechnology, Jilin Agricultural University, Changchun, Jilin, China \\ Correspondence: Peiwu Wang, Center for Plant Biotechnology, Jilin Agricultural University, Changchun, Jilin, \\ China. Tel: 0431-8453-2908. E-mail: peiwuw@163.com
}

Received: February 19, 2017

Accepted: April 19, 2017 Online Published: May 29, 2017

doi:10.5539/jps.v6n2p45

URL: https://doi.org/10.5539/jps.v6n2p45

\begin{abstract}
This experiment was carried out to evaluate genetic stability and disease resistance in transformed soybean lines with hrpZpsta gene using PCR analysis, southern blotting, real-time quantitative PCR (qRT-PCR) and to analyze the resistance against Phytophthora sojae ( $P$. sojae) and Cercospora sojina (C. sojina) after inoculation. The results obtained using PCR and southern blotting analytical methods showed that exogenous gene functional elements were stably inherited in transgenic soybean and hrpZpsta gene was successfully integrated into the soybean genome in a single copy. Results at high-generation $\left(\mathrm{T}_{7}, \mathrm{~T}_{8}\right)$ transgenic lines of hrpZpsta revealed that their relative expression of hrpZpsta gene was the highest in leaves followed by roots, and much lower in stems, flowers, and seeds. Activity change rates of peroxidase (POD), polyphenol oxidase (PPO) and phenylalanine ammonia lyase (PAL) showed that transgenic lines significantly enhanced receptor species. The resistance of transgenic strains $\mathrm{T}_{7}$ and $\mathrm{T}_{8}$ generations against $P$. sojae was significantly increased with artificial inoculation methods, and the resistance against $C$. sojina was increased from susceptibility to the level of resistance. Under natural conditions in the field, the response of $\mathrm{T}_{8}$ transgenic lines to $C$. sojina reached disease resistance level. There were no significant differences in transgenic lines and recipient variety in maturing stage, leaf shape, flower color, plant height, 100-grain weight and quality content, and the two years average yield of plots increased to $11.59 \%$ and $8.19 \%$, which significantly higher than recipient cultivar. The current results provide data support for the release of transgenic lines.
\end{abstract}

Keywords: disease resistance, hrpZpsta gene, genetic transformation, soybean

\section{Introduction}

Soybean (Glycine max L.) is a major food and oilseed crop worldwide and provides the largest source of vegetable oil and protein for humans and animals ( $\mathrm{Li}$, Zhang, Hao, Hua, Duan, Zhang, \& Li, (2013). Its fungal disease is currently a major hurdle restricting the quality of soybean and causes damage to the crop's yield (Li, Luan, \& Liu, 2015). However, the complex physiology of pathogenic bacteria makes it difficult to breed a resistant plant to break through the problem (Dorrance, Jia, \& Abney, 2004; Kim, et al., 2013), and conventional breeding methods have limitations which make it difficult to fulfill the production needs (Molinar, 2012). Therefore, a combination of biotechnology and traditional breeding methods provides a new way to breed for disease resistant varieties and the renewal of germ plasm resources (Kamthan, Chaudhuri, Kamthan, \& Datta, 2016).

Harpin protein is a class of nonspecific protein elicitors encoded by the $h r p$ gene in gram-negative plant pathogenic bacteria which can: excite hypersensitive reaction (HR) in plants; make plants gain broad spectrum disease resistance (Alfano, \& Collmer, 1997; Strobel, Ji, Goplan, Kuc, \& He, 1996); can be induced by different signaling pathways to produce disease, insect and drought resistance and promote plant growth and other beneficial effects (He, Huang, Collmer, 1993; Pandey et al., 2005). Furthermore, it has important theoretical and practical values in the production of better application prospects. The gene encoding harpin protein was transferred into rapeseed (Ma et al., 2008), rice (Cheng \& Xu, 2008), and wheat (Fu et al., 2014), all of which showed significant disease resistance. Studies have shown that harpin protein can induce resistance to 60 kinds of diseases in more than 40 kinds of crops. In addition, the physiological and biochemical mechanisms of resistance in harpin protein shows that it could induce the expression of POD, PPO, PAL and other protective enzymes in tomato, cucumber and eggplant, (Yuan \& Meng, 2008), and as a consequence, induce plant defense 
response and enhance plant resistance to diseases. In transgenic tobacco, hpa1Xoo can increase the POD, PPO, PAL and other defense enzymes, and enhance resistance to tobacco mosaic virus (Han \& Chang, 2013).

The hrpZpsta gene derived from tobacco wildfire pathogen, is a broad-spectrum resistance gene which encodes the harpin protein and effectively stimulates the soybean plant to produce disease defense response so as to effectively improve its disease resistance and reduce yield loss caused by soybean diseases (Dorrance, Jia, \& Abney, 2004; Wu, Zhang, Zhang, Gu, \& Gao, 2017). Bioinformatics analysis showed that the gene and its encoded protein are not toxic for humans and animals. In this study, high-generation $\left(\mathrm{T}_{7}, \mathrm{~T}_{8}\right)$ transgenic lines of hrpZpsta were used to test the genetic stability of transformed hrpZpsta gene and the resistance of the transgenic lines was analyzed. In order to improve the ability of soybean to resist gray leaf spot and phytophthora root rot, it aims to reduce the disease to improve the yield of soybean.

\section{Materials and Methods}

\subsection{Materials and Experimental Design}

\subsubsection{Plant Materials and Strain}

Transformed hrpZpsta gene stable lines JL30-187 and JL30-80 at $\mathrm{T}_{7}$ to $\mathrm{T}_{8}$, receptor cultivar named JL30 were provided by the Plant Biotechnology Center, Jilin Agricultural University, (Changchun, China). $P$. sojae PmC-1 and C. sojae CSJ-1 were provided by the Jilin Academy of Agricultural Sciences, (changchun, China).

\subsubsection{Test Design}

Plant material were planted the randomized block design (three replications) was used in the field trial, used for genetic stability analysis and field surveys. The experimental site is Jilin Agricultural University transgenic crop test base (Changchun, China). It is located in 125.13 degrees east longitude, Latitude 43 degrees 53 minutes north, 236.8 meters above sea level, The annual average temperature of $4.8^{\circ} \mathrm{C}$, frost-free period of 148 days, accumulated temperature of more than $10^{\circ} \mathrm{C}$ is $2921.8^{\circ} \mathrm{C}$, Sunshine $2300-3000$ hours per square centimeter annual radiation $120-130 \mathrm{kcal}$, Annual rainfall of $567 \mathrm{~mm}$, The precipitation in the four seasons is the percentage of the year: the spring (3-5) is $11.4 \%$; the summer (6-8) is $69.5 \%$; the autumn (9-11) is $17.0 \%$, the winter (12-2) is $2 \%$. April average temperature of $7.2^{\circ} \mathrm{C}$, July average temperature of $26.1{ }^{\circ} \mathrm{C}$, September $8.4{ }^{\circ} \mathrm{C}$, is a continental monsoon climate.

\subsection{Genetic Stability Analysis of Target Genes}

Transgenic plants at $T_{7}$ to $T_{8}$ were detected by PCR, Soybean Fresh leaves genome were collected from each of the transformed plants at 60 days after planting and DNA was extracted according to the manufacturer's instruction of NuClean Plant Genomic DNA kit (CWBIO, Beijing, China). Specific primers were designed to target these three genes hrpZpsta, badh and 35s-hrpZpsta-NOS was designed with Primer 5.0 soft ware, and two pairs primers named QhrpZpsta, QActin were designed using the Primer 5.0 software to amplify hrpZpsta and TUB4(reference gene) for real-time quantitative PCR, respectively(Table 1 ).

PCR amplification system was $2.5 \mathrm{uL}$ loading buffer, $2.5 \mathrm{uL} \mathrm{MgCl}, 0.5 \mathrm{uLdNTP}, 1 \mathrm{uL}$ forward primer, $1 \mathrm{uL}$ reverse, 1uLDNA and $0.3 \mathrm{uL}$ Taq, add $\mathrm{DDH}_{2} \mathrm{O}$ to $25 \mathrm{uL}$. hrpZpsta $\mathrm{PCR}$ reaction conditions were pre-denaturation at $94^{\circ} \mathrm{C}$ for $3 \mathrm{~min}$, followed by 36 cycles of $94^{\circ} \mathrm{C}$ for $40 \mathrm{~s}, 54^{\circ} \mathrm{C}$ for $40 \mathrm{~s}, 72^{\circ} \mathrm{C}$ for $40 \mathrm{~s}$, and $72^{\circ} \mathrm{C}$ for $8 \mathrm{~min}$. PCR conditions for the badh were pre-denaturation at $94^{\circ} \mathrm{C}$ for 3 minutes, followed by 40 cycles of $94^{\circ} \mathrm{C}$ for $50 \mathrm{~s}, 54^{\circ} \mathrm{C}$ for $50 \mathrm{~s}, 72^{\circ} \mathrm{C}$ for $50 \mathrm{~s}$, and $72^{\circ} \mathrm{C}$ for $8 \mathrm{~min}$. and 35 s-hrpZpsta-NOS genes were similar to those of hrpZpsta except that $56^{\circ} \mathrm{C}$ annealing temperatures were used.

Table1. Primer sequence of PCR and qRT-PCR

\begin{tabular}{lll}
\hline Primer name & Forward Primer sequence $\left(\right.$ from $5^{\prime}$ to $\left.3^{\prime}\right)$ & Reverse Primer sequence $\left(3^{\prime}\right.$ to $\left.5^{\prime}\right)$ \\
\hline hrpZpsta & ATGCAGAGTCTCAGCTTAAC & TCACCATTGGAATTGCTGTTG \\
35S-hrpZpsta-NOS TTCAGAAAGAATGCTAACCCACAG & TGCGGGACTCTAATCATAAAAACC \\
BADH & TGTCGATCCCTATACCTTC & TTAAGGAGACTTGTACCAC \\
QhrpZpsta & GACTTGATGACACAGGTG & ACCATTGGAATTGCTGT \\
QTUB 4 & GGCGTCCACATTCATTGGA & CCGGTGTACCAATGCAAGAA \\
\hline
\end{tabular}

According to the experimental PCR results, from the genome extracted from $T_{7}$ to $T_{8}$ soybean leaves, the target gene and the marker probe were labeled according to DIG High Prime DNA Labeling and Detection Starter Kit (Roche, America). The genomic DNA was digested with restriction endonuclease for 20 hours. The recombinant 
plasmid digest was separated on $0.8 \%$ agarose gel electrophoresis. The digest was then denatured to enable transfer onto a membrane for further analysis.

RNA was extracted from different tissues (roots, stems, leaves, flowers and seeds) of the plant at anthesis using RNAiso Plus kit (Takara), with three replicates. Using the above RNA as a template, reverse transcription into cDNA was made, and the specific primers were designed with primer 5.0 for the hrpZpsta gene sequence and soybean TUB4 (GeneBank No.EV263740) as shown in Table 1. The relative expression was analyzed using Mx3000P instrument (America), according to manufacturer's instructions for which each sample mRNA were detected three times. The relative quantitative calculation was performed by $2^{-{ }^{\mathrm{CT}}}$ method. CDNA reverse transcription and real-time PCR analysis were performed according to the instructions of All-in-One TM First-strand cDNA Synthesis Kit (GeneCopoeia, beijing China) and All-in-One TM qPCR Mix (GeneCopoeia, beijing China).

\subsection{Enzyme Activity Determination for Resistance against P. Sojae}

In order to eliminate the effects of temperature and humidity on enzyme activity, two sets of parallel experiments were conducted, transgenic lines at $\mathrm{T}_{7}$ generation and non-transgenic receptors were planted at pots, three strains were planted per barrel, each treated three timesa total. After the opposite leaf of soybean plant was completely grown, the hypocotyls were used to induce the test material. one group was inoculated and the other group was not. Leaves were taken at $0 \mathrm{~h}, 24 \mathrm{~h}, 48 \mathrm{~h}, 72 \mathrm{~h}, 96 \mathrm{~h}$ and $120 \mathrm{~h}$ after inoculation. Samples were frozen using liquid nitrogen and placed in $-80{ }^{\circ} \mathrm{C}$ refrigerator for preservation.

Leaves picked at different times to weigh $0.2 \mathrm{~g}$, and $5 \mathrm{ml}$ of sample extract (boric acid buffer $\mathrm{pH} 8.8,5 \mathrm{mmol} / \mathrm{L}$ mercaptoethanol, $1 \mathrm{mmol} / \mathrm{L}$ EDTA and 5\% glycerol) was added to make the homogenate at $6 \times 104 \mathrm{r} / \mathrm{min}, 4{ }^{\circ} \mathrm{C}$ and centrifuged for $20 \mathrm{~min}$. The supernatant was extracted for enzyme solution and placed in $4{ }^{\circ} \mathrm{C}$ refrigerator and then centrifuged again for $20 \mathrm{~min}$. POD, PPO and PAL activities were determined as previously described (Cheng \& Xu 2013; Xu \& Chang, 2014; Zhang, Xu, Wu, \& Chen, 2008). In order to eliminate the background enzyme activity of each strain, the change rate of enzyme activity was taken as the standard.

Change rate of enzyme activity $\%=(\mathrm{A} 1-\mathrm{A} 0 / \mathrm{A} 0) * 100$

where $\mathrm{A}_{1}$ : vaccinated leaves activity.

$\mathrm{A}_{0}$ : unvaccinated leaves activity.

\subsection{Disease Resistance Analysis against P. Sojae and C. Sojae}

$\mathrm{T}_{7}$ and $\mathrm{T}_{8}$ soybeans were tested for $P$. sojae PmC-1, the pathogenic strain of $P$. sojae, by hypocotyl staining method after the soybean leaves were completely grown. After inoculation, keep the wound humidity, shed temperature control in $20-25{ }^{\circ} \mathrm{C}$, humidity maintained at $90 \%$ or more. Investigation and statistics of transgenic lines and control receptor varieties Vaccination rate of Phytophthora infestans at five days after inoculation. Resistance evaluation criteria were: resistant (R)- plant mortality less than $30 \%$; moderately resistant (MR)-mortality rate from $31 \%$ to $69 \%$; susceptible (S)- plant mortality rate of $70 \%$ or more.

In the flowering stage of soybean to the early flowering stage of inoculation, the foliar leaching method was used to test the inoculation test of $\mathrm{T}_{7}$ transgenic lines and acceptor varieties. After the inoculation, the humidity was $80 \%-100 \%$, the control temperature was about $25-27^{\circ} \mathrm{C}$, and the disease was investigated after 15 days. The incidence and incidence of the whole soybean were counted. To evaluate the resistance to gray leaf spot at field natural environment, soybean plants at the T8generation at flowering stages were Investigation, using the diagonal 5 points sampling, each investigation 100 cases. Soybean resistance to gray spot disease identification of disease levels, the use of 1-9 ratio assessment, 1 represents no disease spots, 9 on behalf of the leaves there are many lesion area of more than 50\%. Specific resistance evaluation criteria are: immune (IM), the disease index was 0; high resistance (HR), disease index of 2 and below; disease resistance (R), disease index was 2.1 15.0; moderately resistant (MR), disease index was 15.1 40.0; moderately susceptible (MS), disease index was 40.1 60; susceptible (S), disease index was 60.1 80; highly susceptible (HS), disease index of 80 or more.

\subsection{Analysis of Agronomic Traits}

During anthesis, the phenotypic characters of the plant material at $\mathrm{T}_{7}$ to $\mathrm{T}_{8}$ were investigated. After maturation, 10 plants were randomly selected from each plot to investigate the agronomic traits of yield, including growth period, leaf shape, color, coat color, plant height, node, 100-see weight, branches, Pods, seed weight, plot yield. NIRS DS2500 (Denmark) was used to analyze the quality of plant material at $\mathrm{T}_{8}$ generation. The yield of the plot was measured and the data were statistically analyzed by MS Exceland DPS data processing system. 


\section{Results and Analysis}

\subsection{Genetic Stability Analysis of Target Genes}

The results of PCR detection of the target gene are shown in Fig. 1a. Target gene hrpZpsta, 35S-hrpZpsta-NOS expression full-length sequence screening marker, and gene $B A D H$ were detected in the $\mathrm{T}_{7}$ and $\mathrm{T}_{8}$ generation in transgenic soybean lines. The effect of exogenous inserts of different generations in transgenic soybeans was genetically stable.

The results of Southern blot analysis of hrpZpsta gene are shown in Fig. 1b. Hybridization bands were detected in $\mathrm{T}_{7}$ and $\mathrm{T}_{8}$ transgenic soybean lines, while the receptor was not detected in the control sample. The target gene hrpZpsta was integrated at different sites into the recipient genome in a single copy, andwas stably inherited in the transgenic lines.

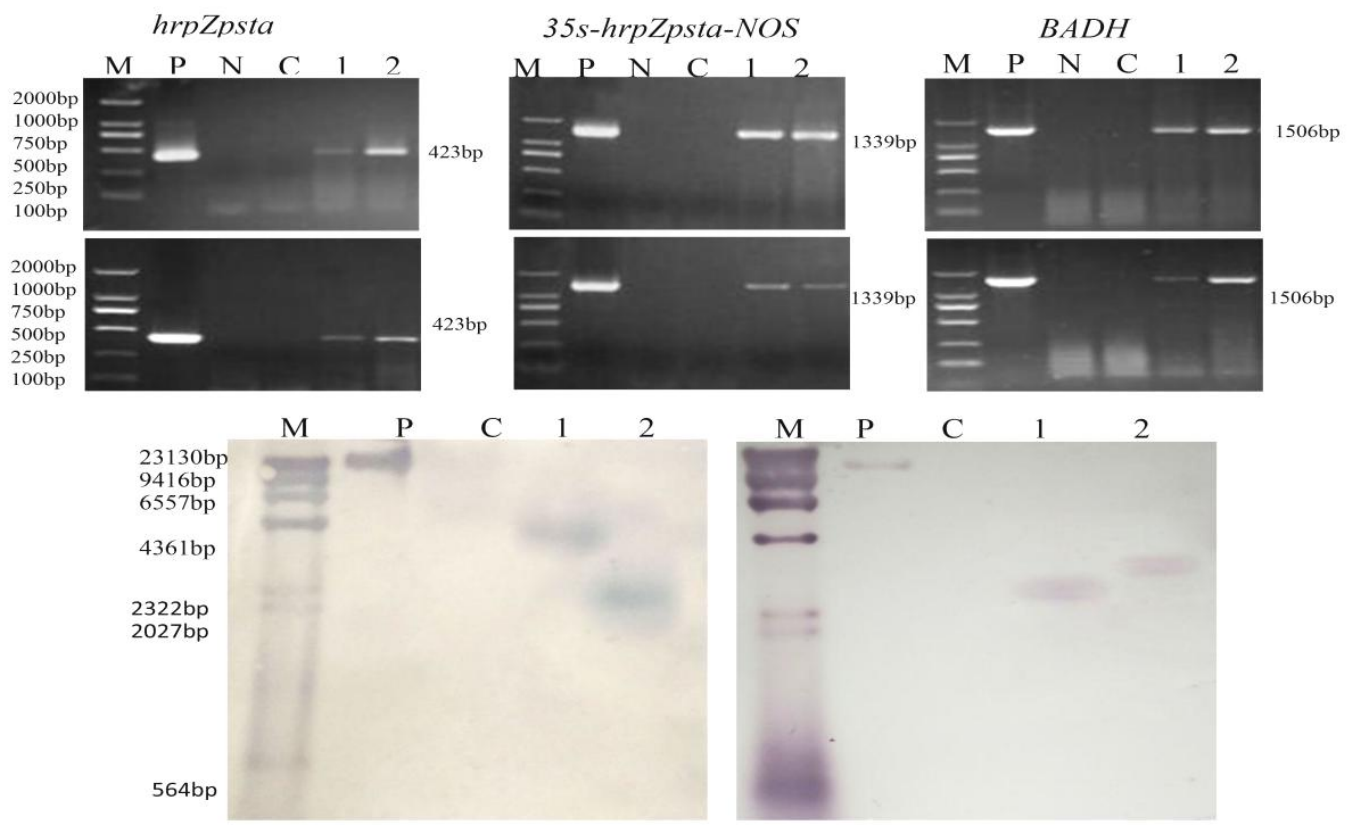

Figure 1. Genetic stability analysis of target genes

Note: (a): PCR analysis of T7 and T8 positive transgenic lines using hrpZpsta, 35s-hrpZpsta-NOS, and badh primer, respectively. (Note: M= DL2000 DNA marker, P= Positive control, N= Negative control, C= CK Jilin30, 1= Transformed Line JL30-187, 2= Transformed Line JL30-80). (b): Southern blot analysis of T7 and T8 transgenic plants (M=Southern DNA marker, $\mathrm{P}=$ Positive control, $\mathrm{C}=\mathrm{CKJ}$ ilin30, 1-2= transgenic soybean plants).

The results showed that the target gene hrpZpsta was expressed in the roots, stems, leaves, flowers and grains of soybean (Fig. 1). The relative expression level of hrpZpsta gene in T7 generation transgenic soybean lines was the highest while the relative expression average of JL30-187 and JL30-80 were 8.477 and 6.971, respectively. In the roots, the average relative expression of JL30-187 and JL30-80 were 4.903 and 5.816, respectively. The expression levels of JL30-187 in stems, flowers and grains were lower at 1.423, 1.467 and 0.756, respectively, while the average expression levels were $0.686,0.757$ and 0.683 , respectively for JL30-80. The relative expression level of hrpZpsta gene in T8 generation transgenic soybean lines was the highest with a relative expression average of 9.237 in JL30-187 and of 6.67 for JL30-80. In the roots, the average relative expression of JL30-187 and JL30-80 were 5.495 and 4.754, respectively. The expression levels in stems, flowers and grains were low. The results showed that the expression level of the target gene in different tissues was different. The gene of hrpZpsta and the transgenic materials could be stably expressed in different generations.

\subsection{Enzyme Activity Determination against P. Sojae}

The changes in enzyme activities of the transgenic line JL30-187 and receptor cultivar JL30 after inoculation with P. sojae are shown in Fig. 2. The change rates of POD, PPO and PAL activities in the leaves of the transgenic line showed no significant changes $(\mathrm{P}<0.01)$ after $0 \mathrm{~h}$ and $120 \mathrm{~h}$ inoculation. However, $24 \mathrm{~h}$ inoculation resulted in a change rate in POD activity in the transgenic line, being $181.39 \%$ higher than in the recipient cultivar. After $48 \mathrm{~h}$ inoculation, the rate of change in POD and PAL activities in the transgenic lines for the receptor species increased by $273.95 \%$ and $464.99 \%$, respectively. After $72 \mathrm{~h}$ inoculation, POD, PPO and 
PAL activities in the leaves (transgenic lines) of receptor species increased to $156.52 \%, 127.91 \%$ and $106.99 \%$, respectively. The activity change rate in POD, PPO and PAL in transgenic lines increased to $163.76 \%, 60.58 \%$ and $27.51 \%$, respectively compared with the recipient cultivars after $96 \mathrm{~h}$ inoculation. The results showed that the activity of disease-resistant enzymes increased in the transgenic lines, which could be one of the causes of the resistance of the transgenic plants to infection by pathogenic fungi.
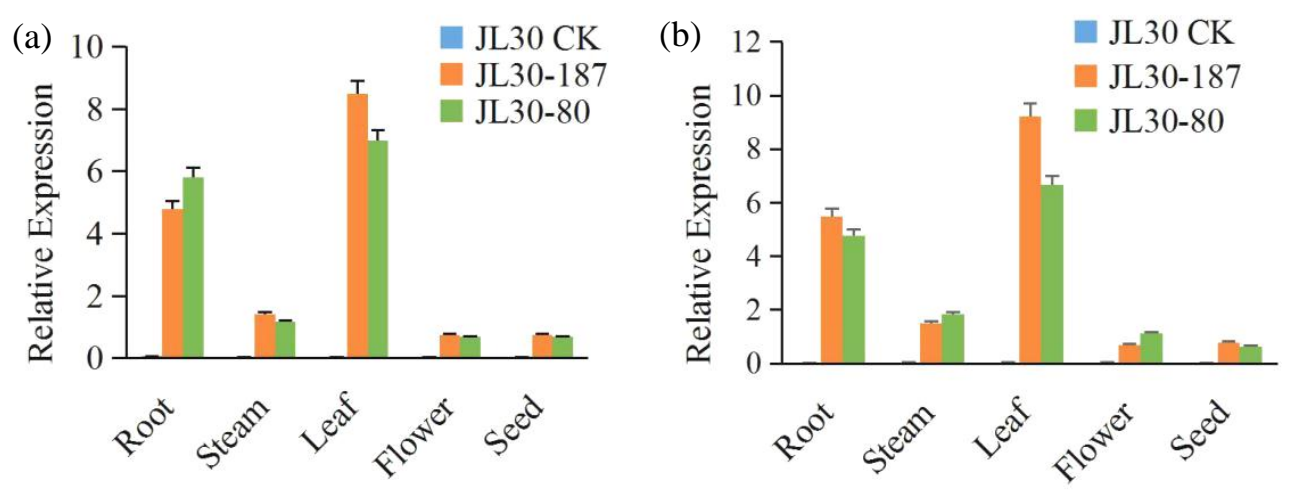

Figure 2. Analysis of target gene expression stability

Note: (a): T7 generation expression of hrpZpsta gene in different parts of plants. (b): T8 generation expression of hrpZpsta gene in different parts of plants.

(a)

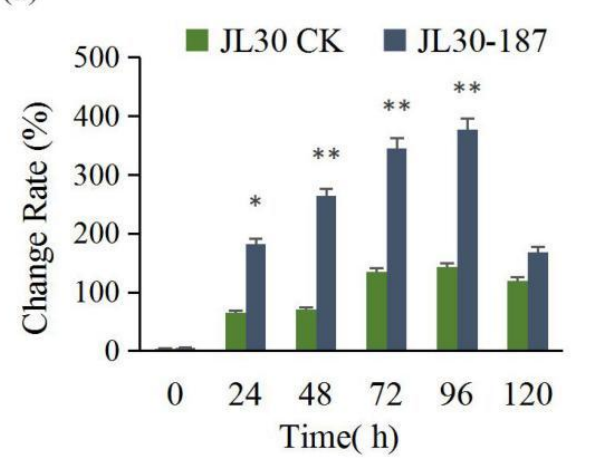

(b)

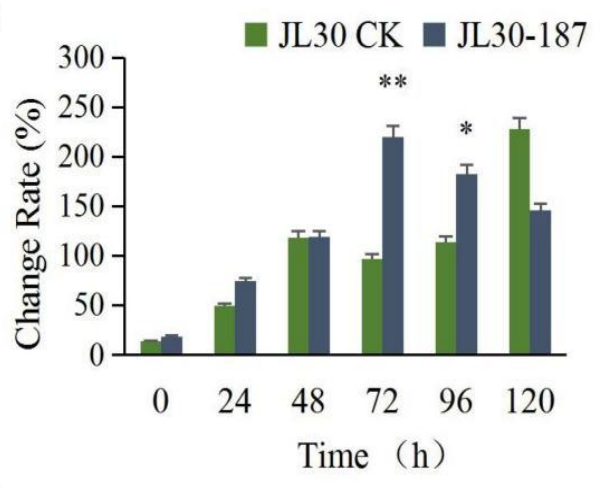

(c)

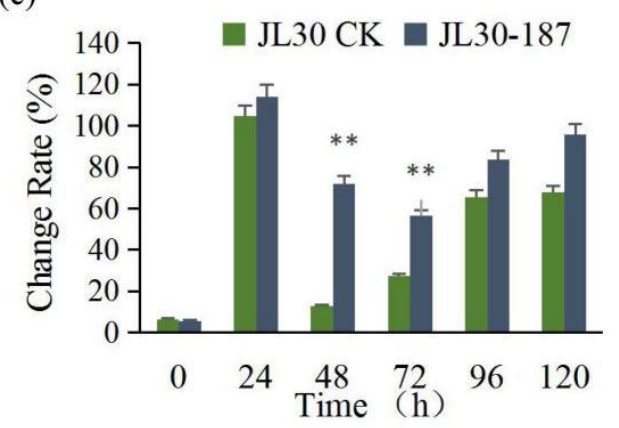

Figure 3. Changes in enzyme activity of leaves after inoculation with $P$. sojae

(a): POD activity change rate. (b): PPO activity change rate. (c): PAL activity change rate. ${ }^{*}$ Indicates that the difference in treatment level was significant at 0.05 level $(\mathrm{p}<0.05)$. ** Indicates that the difference in treatment level was significant at 0.01 level $(\mathrm{p}<0.01)$.

\subsection{Disease Resistance Analysis of P. Sojae and C. Sojina}

Identification vaccination of $P$. sojae results are shown in Table 2 and Fig. 3. During the continuous 2-year comprehensive evaluation, JL30-187 and JL30-80 inoculation mortality rates were $6.94 \%$ and $19.44 \%$, respectively, as all showed $\mathrm{R}$. In the recipient variety, JL 30 inoculation mortality rate was $50.00 \%$, the performance of the MR. The resistance of the transgenic lines to Phytophthora root rot was evaluated from the MR to the R level. 
Table 2. Identification vaccination $P$. sojae

\begin{tabular}{lllllll}
\hline \multicolumn{6}{c}{ Generation Cultivar and lines Detected } & \multicolumn{5}{c}{ Nolive } & No. Death & No. Death rate (\%) Resistance reaction \\
\hline \multirow{2}{*}{$\mathrm{T}_{7}$} & JL30 CK & 18 & 9 & 9 & 50 & MR \\
& JL30-187 & 18 & 17 & 1 & 5.55 & $\mathrm{R}$ \\
& JL30-80 & 18 & 15 & 3 & 16.67 & $\mathrm{R}$ \\
$\mathrm{T}_{8}$ & JL30 CK & 36 & 15 & 15 & 50 & MR \\
& JL30-187 & 36 & 33 & 3 & 8.33 & $\mathrm{R}$ \\
& JL30-80 & 36 & 28 & 8 & 22.22 & $\mathrm{R}$ \\
\hline
\end{tabular}

Identification results of C. sojina are shown in Table 3. From Fig. 4, it can be seen that the lesion is obvious on the leaves of the recipient plant and the spots on the leaves of transgenic progeny are relatively few. Artificial inoculation results showed that $\mathrm{T}_{7}$ transgenic lines JL30-187 and JL30-80 disease index was $16.94 \%$ of which $16.42 \%$ showed MR; receptor species JL30 disease index was $61.59 \%$, expressed as S. The resistance of the transgenic lines to gray leaf spot was improved from $\mathrm{S}$ to MR.

The results of field investigation showed that the disease index of JL30-187 was 13.93\% and JL30-80 was $14.60 \%$, which indicated R. The disease index of JL30 was $60.29 \%$ thus indicating S. Resistance evaluation of transgenic lines to gray leaf spot was improved from $\mathrm{S}$ to $\mathrm{R}$ level.

Table 3. Identification of Resistance to C.sojina

\begin{tabular}{|l|l|l|l|l|}
\hline Method & Cultivar and line & Death rate (\%) & Disease index & Resistance evaluation \\
\hline \multirow{4}{*}{ Artificial vaccination (T7) } & JL30-CK & 96.67 & $61.59 \pm 2.35 \mathrm{~A}$ & $\mathrm{~S}$ \\
\cline { 2 - 5 } & JL30-187 & 78.33 & $16.42 \pm 1.35 \mathrm{AB}$ & $\mathrm{MR}$ \\
\cline { 2 - 5 } & JL30-80 & 76.67 & $17.33 \pm 2.15 \mathrm{AB}$ & $\mathrm{MR}$ \\
\hline \multirow{3}{*}{ Field investigation (T8) } & JL30-CK & 90.67 & $60.29 \pm 2.45 \mathrm{~A}$ & $\mathrm{~S}$ \\
\cline { 2 - 5 } & JL30-187 & 49.67 & $13.93 \pm 1.65 \mathrm{AB}$ & $\mathrm{R}$ \\
\cline { 2 - 5 } & JL30-80 & 50.33 & $14.60 \pm 3.25 \mathrm{AB}$ & $\mathrm{R}$ \\
\hline
\end{tabular}

Note:The data in the table are mean \pm standard deviation, Different lowercase letters indicate that the difference in treatment level is significant $(\mathrm{p}<0.01)$.

\subsection{Investigation of Agronomic Traits}

The results of agronomic traits at $\mathrm{T}_{7}$ and $\mathrm{T}_{8}$ are shown in Table 4 . The growth period of the transgenic lines were 132 days with the sharp leaves, gray hairs, white flowers and podding habits sub-limited and yellow-hued indicative of no significant differences from the recipient cultivar. Pod numbers and total grain weight were significantly different from those of recipients $(\mathrm{p}<0.5)$. The yield of JL30-187 and JL30-80 increased 9.47\% and $4.54 \%$, respectively, compared to the control plot in 2015, and the yield of the plot increased by $13.46 \%$ and $11.83 \%$ in 2016.

2016 seed quality test results are shown in Table 5. Seed protein content of JL30-187 and JL30-80 were reduced by $3.59 \%$ and $0.52 \%$, respectively, compared with JL30 and fat content decreased by $2.08 \%$ and $3.45 \%$. There were no significant differences in the contents of amino acids and fatty acids between transgenic lines and recipient cultivar. 

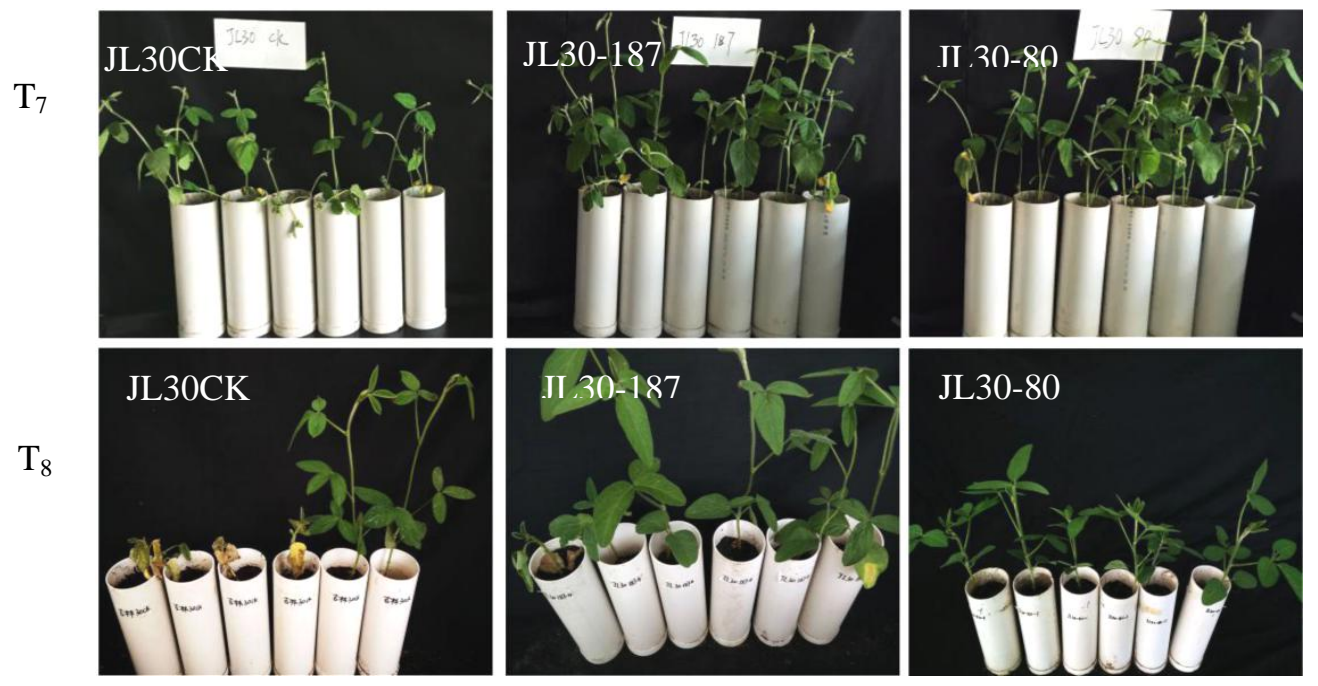

Figure 4. Identification of resistance against $P$. Sojae

Artificial vaccination
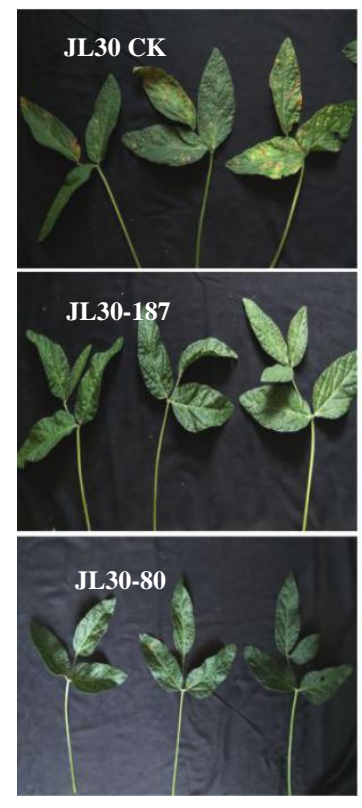
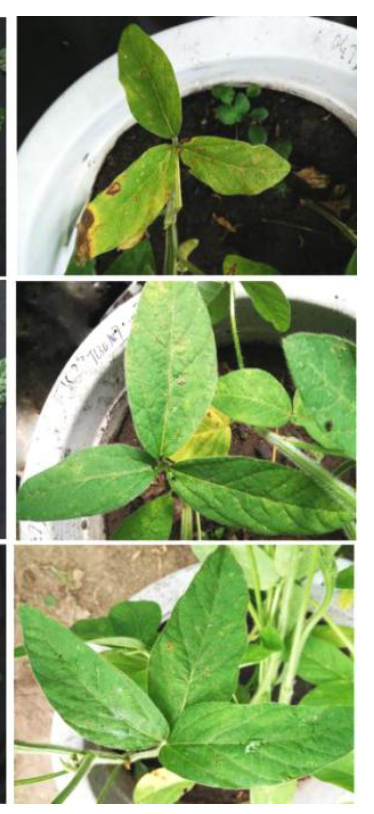

Field investigation
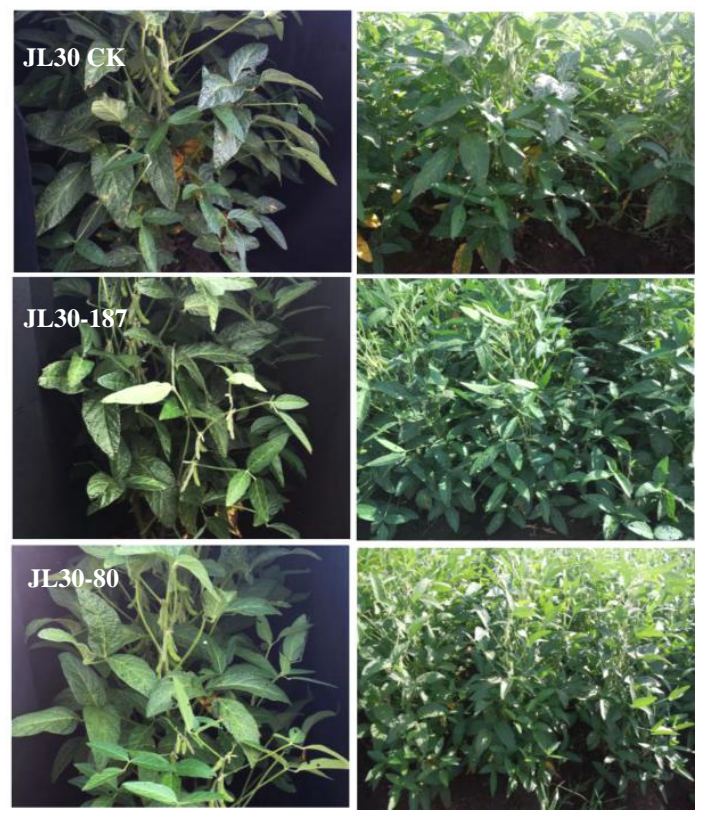

Figure 5. Identification of Resistance to C.sojina

Table 4. Investigation on Field Phenotypic Traits of transgenic lines

\begin{tabular}{|c|c|c|c|c|c|c|c|c|c|}
\hline generation & Material & Plant height & Node & 100 -seed weight & Branches & Pods & Seed weight & Yield $\left(\mathrm{m}^{2}\right)$ & Increasing rate $(\%)$ \\
\hline \multirow{3}{*}{$\mathrm{T}_{7}$} & JL30 CK & $98.37 \pm 0.85 a$ & $17.6 \pm 0.08 \mathrm{a}$ & $17.21 \pm 0.15 \mathrm{a}$ & $1.90 \pm 0.21 \mathrm{a}$ & $62.37 \pm 5.37 \mathrm{a}$ & $29.35 \pm 2.61 \mathrm{a}$ & $0.404 \pm 0.24 a$ & \\
\hline & JL30-187 & $101.67 \pm 0.12 \mathrm{a}$ & $17.67 \pm 0.12 \mathrm{a}$ & $17.31 \pm 0.35 \mathrm{a}$ & $2.23 \pm 0.40 \mathrm{a}$ & $69.10 \pm 2.84 \mathrm{a}$ & $32.71 \pm 0.98 \mathrm{a}$ & $0.475 \pm 0.37 \mathrm{a}$ & 9.71 \\
\hline & JL30-80 & $101.30 \pm 0.57 \mathrm{a}$ & $17.87 \pm 0.05 \mathrm{a}$ & $17.57 \pm 0.17 \mathrm{a}$ & $2.5 \pm 0.08 \mathrm{a}$ & $64.77 \pm 1.61 \mathrm{a}$ & $31.13 \pm 0.98 \mathrm{a}$ & $0.408 \pm 0.19 a$ & 4.54 \\
\hline \multirow{3}{*}{$\mathrm{T}_{8}$} & JL30 CK & $89.57 \pm 0.26 \mathrm{a}$ & $16.37 \pm 0.32 a$ & $19.36 \pm 0.05 a$ & $0.37 \pm 0.05 \mathrm{a}$ & $29.7 \pm 1.65 \mathrm{a}$ & $11.77 \pm 0.13 a$ & $0.362 \pm 0.63 \mathrm{a}$ & \\
\hline & JL30-187 & $92.03 \pm 0.37 \mathrm{a}$ & $16.63 \pm 0.05 \mathrm{a}$ & $19.31 \pm 0.06 \mathrm{a}$ & $0.50 \pm 0.08 \mathrm{a}$ & $40.60 \pm 1.13 b$ & $16.84 \pm 0.17 b$ & $0.418 \pm 0.56 \mathrm{~b}$ & 13.46 \\
\hline & JL30-80 & $93.10 \pm 0.45 \mathrm{a}$ & $16.67 \pm 0.12 \mathrm{a}$ & $19.84 \pm 0.03 \mathrm{a}$ & $0.53 \pm 0.05 \mathrm{a}$ & $37.90 \pm 2.11 \mathrm{~b}$ & $17.31 \pm 1.40 \mathrm{~b}$ & $0.412 \pm 0.49 b$ & 11.83 \\
\hline
\end{tabular}

Note: The data in the table are mean \pm standard deviation, Different lowercase letters indicate that the difference in treatment level is significant $(\mathrm{p}<0.05)$. 
Table 5. Seed quality analysis of $\mathrm{T}_{8}$ transgenic lines

\begin{tabular}{|c|c|c|c|c|c|c|c|c|c|c|c|}
\hline $\begin{array}{l}\text { Quality } \\
\text { Cultivar }\end{array}$ & Protein & Fat & CYS & ARG & MET & PHE & C160 & $\mathrm{C} 180$ & $\mathrm{C} 181$ & $\mathrm{C} 182$ & $\mathrm{C} 183$ \\
\hline JL30 CK & $40.08 \pm 0.31$ & $21.13 \pm 0.33$ & $0.53 \pm 0.00$ & $3.01 \pm 0.05$ & $0.45 \pm 0.00$ & $2.08 \pm 0.02$ & $9.34 \pm 0.11$ & $3.25 \pm 0.13$ & $12.63 \pm 0.33$ & $62.21 \pm 0.27$ & $4.33 \pm 0.21$ \\
\hline JL30-187 & $38.64 \pm 0.72$ & $20.69 \pm 0.11$ & $0.52 \pm 0.00$ & $2.88 \pm 0.08$ & $0.42 \pm 0.03$ & $2.05 \pm 0.03$ & $9.18 \pm 0.13$ & $3.35 \pm 0.21$ & $12.86 \pm 0.79$ & $61.60 \pm 0.53$ & $4.36 \pm 0.27$ \\
\hline JL30-80 & $39.87 \pm 0.40$ & $20.4 \pm 0.16$ & $0.53 \pm 0.00$ & $2.97 \pm 0.02$ & $0.44 \pm 0.01$ & $2.09 \pm 0.00$ & $9.04 \pm 0.11$ & $3.28 \pm 0.11$ & $12.32 \pm 0.51$ & $62.39 \pm 0.21$ & $4.10 \pm 0.16$ \\
\hline
\end{tabular}

Note: The data in the table are mean \pm standard deviation.

\section{Results and Discussion}

The preliminary work of this experiment proved that $\mathrm{T}_{1}-\mathrm{T}_{6}$ generations of transgenic lines of the target gene can be stable (Zhang \& Qu2011; Yin, Wang, Zhang, \& Ma, 2013; Gu, Liu, \& Wang, 2015). This study analyzes the genetic stability of target genes in T7, T8 transgenic lines; whether the presence of the primary PCR, the number of copies verified by Southern blotting or the expression of the transcriptional level detected by qRT-PCR confirmed that the transformed hrpZpsta gene was stably inherited and expressed in the recipient cultivar.

In recent years, a number of genetically modified soybean germ plasm have been obtained by genetic engineering. Zhou et al (2014) transferred GmAKT2 gene into Williams82 to obtain transgenic material resistant to soybean mosaic virus disease. Fan et al $(2012 ; 2015)$ cloned resistance genes SDR1 and Glym4l from anti-Phytophthora sojae variety Suinong 10, and transferred them into the susceptible cultivar Dongnong 50 to significantly increased its Phytophthora root rot capacity. Zhang, (2011) transferred BnERF104 gene into Dongnong 50 and obtained significantly reduced lesion area of genetically modified soybean material. In this study, hrpZpsta gene was a broad-spectrum disease resistance gene, and its progenies were significantly improved in resistance to Phytophthora root rot and soybean gray leaf spot under indoor artificial inoculation conditions. The natural disease incidence of gray leaf spot disease in the field showed that the resistant ability of the transgenic lines reached the R level, which further proved the general resistance of the hrpZpsta gene.

Plant disease severity and disease resistance and plant defense enzyme activity changes are closely related (Qin, Sun, Zhao, Zhao, \& Zhao,.2014; Liu et al., 2011). The results showed that the activities of POD, PPO and PAL in the transgenic lines increased rapidly after inoculation with $P$. sojae. The activity level was significantly higher than non-transgenic varieties, but the activity change rates of PAL, PPO and POD in the transgenic line was not significantly higher than in the untransformed variety which indicated that transformed hrpZpsta gene soybean had the ability to respond quickly to pathogen infection. This is consistent with reports of other plants on enzyme activity (Shi et al., 2014; Lei et al., 2010).

The results showed that there were no significant changes in the growth period, leaf shape, coat color, flower color, podding habit, hilum color, protein content and fat content of the transgenic lines.However, the number of pods per plant and plot yield were higher than that of the receptor control which may be associated with the insertion of the disease-resistance hrpZpsta gene as it reduces the risk of pathogens. Similar results have also been reported on other transgenic crops (Zhao, Zhu, Cai, Bai, \& Ji, 2012; Guo, Zhu, Li, Bai, \& Cai, 2008).

\section{Conclusion}

Molecular biology test, disease resistance analysis and agronomic traits of transgenic high-generation lines showed that transformed hrpZpsta gene has stable inheritance, and this significantly enhanced soybean root rot and gray leaf spot resistance. The main agronomic traits of the transgenic lines were not significantly different from recipient variety, but the number of pods per plant and plot yield were significantly higher than in the recipient variety. High-generation transgenic soybean lines showing resistance to Phytophthora root rot and $C$. sojina were obtained, which provides data support and theoretical basis for environmental release of transgenic lines.

\section{Acknowledgments}

We thank the Jilin Academy of Agricultural Sciences for providing the pathogenic bacteria of PmC-1 and Cjs-1 and the Jilin Agricultural University Professor Gao Jie for providing the hrpZpsta gene. This research was funded by Grants from the National Science and Technology Major Project (2016ZX08004004-003).

\section{References}

Alfano, J. R., \& Collmer, A. (1997). The type III (Hrp) secretion pathway of plant pathogenic bacteria:Trafficking harpins, Avr proteins, and death. Journal of Bacteriology, 179(18), 5655-5662. https://doi.org/10.1128/jb.179.18.5655-5662.1997 
Chen, L., Zhang, S., Qu, S., Long, J., Yin, Q., Qian, J., Sun, F., \& Zhang, S. (2008). A selected fragment of HpaGXooc, a harpin protein from Xanthomonas oryzae pv. oryzicola, affects disease reduction and grain yield of rice in extensive grower plantings. Phytopathology, 98, 792-802. https://doi.org/10.1094/PHYTO-98-7-0792

Cheng, P., \& Xu, P. F. (2013). The activity of wild soybean after inoculation of Phytophthora root rot fungus peroxidase (POD). Soybean Science, 02, 197-201.

Dong, H., Peng, J., Bao, Z., Meng, X., Bonasera, J. M., Chen, G., \& Beer, S. V. (2004).Downstream divergence of the ethylene signaling pathway for harpin-stimulated Arabidopsis growth and insect defense. Plant Physiol, 136, 3628-3638. https://doi.org/10.1104/pp.104.048900

Dorrance, A. E., Jia, H., \& Abney, T., S. (2004). Evaluation of soybean differentials for their interaction with Phytophthora sojae. Plant Health Prog. https://doi.org/10.1094/PHP-2004-0309-01-RS

Fan, S. J. (2012). Cloning and Functional Analysis of SDR1 Gene Related to Phytophthora Root Rot Resistance in Soybean. Chinese Journal of Agricultural Science, 45(11), 2139-2146.

Fan, S., Jiang, L., Wu, J., Dong, L., Cheng, Q., Xu, P., \& Zhang, S. (2015). A Novel Pathogenesis-Related Class 10 Protein Gly m 41, Increases Resistance upon Phytophthora sojae Infection in Soybean (Glycine max [L.] Merr.). PLoS One, 10(10). https://doi.org/10.1371/journal.pone.0140364

Fu, M., Xu, M., Zhou, T., Wang, D., Tian, S., Han, L., ... Zhang, C. (2014). Transgenic expression of a functional fragment of harpin protein Hpa1 in wheat induces the phloem-based defence against English grain aphid. $J$ Exp Bot, 65(6), 1439-53. https://doi.org/ 10.1093/jxb/ert488

Gu, X. N., Liu, Z., K., \& Wang, P., W. (2015). Study on the realationship between the hrpZpsta resistance gene expression in transgenic soybean and resistance to gary leaf spot disease. Atlantis Press, International Coference on Applied Science an Engineering Innovation (ASEI 2015, China), 1195-1203.

Guo, Y. S., Zhu, Y. M., Li, J., Bai, X., \& Cai, H. (2008). Study and Analysis on Main Agronomic Characters of Transgenic Bifurcated Antifungal Genes. Journal of Northeast Agricultural University, 01, 10-12.

Han, Y. Y., \& Chang Y. W. (2013). The Defense Enzyme Activity in Transgenic Truncated hpa1_(Xoo) Gene Tobacco. Anhui Agricultural Sciences, 41(22), 9197-9199.

He, S. Y., Huang, H. C., \& Collmer, A. (1993). Pseudomonas syringae pv. Syringae harpinPss:A protein that is secreted via the Hrp pathway and elicits thehypersensitive response in plants. Cell, 73, 1255-1266. https://doi.org/10.1016/0092-8674(93)90354-S

Kamthan, A., Chaudhuri, A., Kamthan, M., \& Datta, A. (2016). Genetically modified (GM) crops: milestones and newadvances in crop improvement. Theor Appl Genet, 129(9), 1639-55. https://doi.org/10.1007/s00122-016-2747-6.

Kim, H., Newell, A. D., Cota-Sieckmeyer, R. G., Rupe, J. C., Fakhoury, A. M., \& Bluhm, B. H. (2013) Mating-type distribution andgenetic diversity of Cercospora sojina populations on soybean from Arkansas: evidence for potential sexual reproduction. Phytopathology, 103, 1045-1051. https://doi.org/10.1094/PHYTO-09-12-0229-R

Lei, J. R., Wang, D. M., Li, J. P., Huang, L. P., \& Li, X. R. (2010). Analysis on the Defense Enzyme Activity in Transgenic Cotton Transferring SNC1 Gene Inoculated with Fusarium oxysporum f. sp. Disinfectant. Acta Agriculturae Boreali-Sinica, 24, 9-13.

Li, J. B., \& Luan, Y. S., \& Liu, Z. (2015). SpWRKY1 mediates resistance to Phytophthora infestans and tolerance to salt and drought stress by modulating reactive oxygen species homeostasis and expression ofdefense related genes in tomato. Plant Cell Tissue and Organ Culture, 123, 67-81. https://doi.org/10.1007/s11240-015-0815-2

Li, Y., Zhang, J., Hao, L., Hua, J., Duan, L., Zhang, M., \& Li, Z. (2013). Expression of an Arabidopsis molybdenum cofactor Sulphura-segene in soybean enhances drought tolerance and increases yield under field conditions. Plant Biotechnology Journal, 11, 747-758. https://doi.org/ 10.111/pbi.12066

Liu, H., Zhou, X., Dong, N., Liu, X., Zhang, H., \& Zhang, Z. (2011). Expression of a wheat MYB gene in transgenic tobacco enhances resistance to Ralstonia solanacearum, and to drought and salt stresses. Funct Integr Genomics, 11, 431. https://doi.org/ 10.1007/s10142-011-0228-1

Ma, L. L., Huo R., Gao W., He D., Shao M., \& Wang Q.(2008). Transgenic Rape with hrf2 Gene Encoding Harpinxooc Resistant to Sclerotinia sclerotinorium. Agricultural Sciences in China, 04, 455-461. 
https://doi.org/10.1016/S1671-2927(08)60089-9

Molinar, R. (2012).Traditional plant breeding vs. genetic engineering a primer.IOP Publishing Western Farm Press Web. http://westernfarmpress.com/management.

Pandey, A. K., Ger, M. J., Huang, H. E., Yip, M. K., Zeng, J., \& Feng, T. Y. (2005). Expression of the Hypersensitive Response-assisting Protein in Arabidopsis Results in Harpin-dependent Hypersensitive Cell Death in Response to Erwinia carotovora. Plant Mol Biol., 59, 771-80. https://doi.org/10.1007/s11103-005-1002-3

Qin, L. J., Sun, H. R., Zhao, D., Zhao, J. H., \& Zhao, D. G. (2014). Overexpression of NrCN gene improved the TMV resistance in Nicotiana tabacum L. Journal of Plant Physiology, 04, 439-446.

Shi, W., Hao, L., Li, J., Liu, D., Huo, X., \& Li, H. (2014). The Gossypium hirsutum WRKY gene GhWRKY39-1promotes pathogen infection defense responses and mediates salt stress tolerance in transgenic Nicotiana benthamiana. Plant Cell Rep, 33, 483. https://doi.org/ 10.1007/s00299-013-1548-5

Strobel, N. E., Ji, C., Goplan, S., Kuc, J. A., \& He, S. Y. (1996). Induction of systemic acquired resistance in cucumber by Pseudomonas syringae pv. Syringae 61 HrpZPss protein. The Plant Journal, 9(4), 431-439.

Wu, H., Zhang, Y., Zhang, H., Gu, Q., \& Gao, X. (2017). Identification of functional regions of the HrpZPsg protein from Pseudomonas savastanoi pv. glycinea that induce disease resistance and enhance growth in plants. Eur J Plant Pathol, 147, 55. https://doi.org/10.1007/s10658-016-0979-6

Xu, P. F., \& Chang J. L. (2012). Polyphenol oxidase (PPO) activity of wild soybean inoculated with Phytophthora sojae. Soybean Science, 01, 99-102. https://doi.org/ 10.1007/s10681-016-1749-4

Yin, J. Q., Wang, P. W., Zhang, Z., \& Ma, J. (2013). Study on the relationship between the hrpZpsta resistance gene expression in transgenic soybean and resistance to gray leaf spot disease. Soybean Science, 02, 238-241.

Yuan, R. L., \& Meng, X. L. (2008). Effect of HrpZ Excitation on Activities of Defense-related Enzymes in Several plants. Journal of Anhui Agricultural Sciences, 36(32), 13951-13953

Zhang, S. Zh., Xu, P. F., Wu, J., \& Chen, W. (2008). Change of Phenylalanine Ammonia-lyase (PAL) Activities among Different Resistance Soybean Varieties Treated with Pathotoxin from Phytophthora sojae. Crops, 01, $47-420$.

Zhang, B. (2011). Study on Resistance Identification of Cercospora sojina and Resistance to Gray Leaf Spot in BnERF104 Soybean. Chinese Society of Plant Pathology.Chinese Society of Plant Pathology 2011 Annual Conference Proceedings. Chinese Plant Pathology Society, 1.

Zhang, Y. Y., \& Qu, J. (2011). Studies on transgenic soybean with hrpZpsta resistance. Journal of Northwest A \& F University (Natural Science Edition), 09, 86-92

Zhao, Y., Zhu, Y. M., Cai, H., Bai, X., \& Ji, W. (2012). Research and Analysis on the Agronomic Traits of Salt Tolerant OsCDPK7 and OsMAPK4 Rice. Crop, 05, 22-25.

Zhou, L., He, H. Liu, R., Han, Q., Shou, H., \& Liu, B. (2014). Overexpression of GmAKT2 potassium channel enhances resistance to soybean mosaic virus. BMC Plant Biol, 14(154), 1-11.

https://doi.org/10.1186/1471-2229-14-154

\section{Copyrights}

Copyright for this article is retained by the author(s), with first publication rights granted to the journal.

This is an open-access article distributed under the terms and conditions of the Creative Commons Attribution license (http://creativecommons.org/licenses/by/4.0/). 